\title{
Standardization of complementary work time in timber harvesting processes
}

\author{
Krzysztof Kamiński ${ }^{1}$, Grzegorz Szewczyk ${ }^{2}$,Janusz Kocel \\ ${ }^{1}$ Regional Directorate State Forests in Radom, Kozienice Forest District, Partyzantów 62, 26-670 Pionki, Poland, \\ e-mail: krzysztof.kaminski@radom.lasy.gov.pl \\ ${ }^{2}$ University of Agriculture in Krakow, Faculty of Forestry, al. 29 Listopada 46, 31-425 Kraków, Poland \\ ${ }^{3}$ Forest Research Institute, Department of Forest Resources Management, Sękocin Stary, Braci Leśnej 3, 05-090 Raszyn, \\ Poland
}

\begin{abstract}
One of the essential elements of work technology assessment is task performance time. In the working day structure, production times are crucial; however, under certain conditions, complementary work times can have a share of up to $30 \%$. Accurate determination of the time structure of a work shift is very time consuming and requires time measurements using the methods of cumulative timing or snapshot observations. For this reason, the overall share of complementary work times in a work shift is usually estimated roughly, equally for all timber harvesting conditions. The aim of this study was to determine the impact of selected working environment factors on the share of complementary work times in a work shift, in technologies on the manual-machine and the machine levels. The analyses were carried out in 33 forest districts of the Regional Directorate of State Forests in Wrocław. Among forest contractors, surveys were carried out to analyse the time structure of a working day. For each forest district, analyses of environmental factors potentially relevant to the share of complementary work times in a work shift were carried out; these included field features, dispersion of stands, features of timber, area accessibility. The total share of complementary work times in the machine-level technology variant amounted to approx. $40 \%$ and was higher than the manual-machine technological variant, where this share amounted to approx. $35 \%$. The models developed for standardization of the share of variability of complementary work times, in the case of the manual-machine technology level, took into account the share of timber assortments with the length of over $2.5 \mathrm{~m}$ as well as the share of upland and mountain sites. In the case of timber harvesting at the machine technology level, the standardization model included as significant the factors such as the share of coniferous forest sites, the number of forest complexes with an area of over 100 hectares, and the total length of roads. Therefore, the above features could be selected as decisive for the share of the complementary work time category out of the full set of environmental variables taken into consideration in the estimation of the time-consumption of timber harvesting processes.
\end{abstract}

\section{KeY WORDS}

logging, working time modelling of work time, classification, complementary time of work 


\section{INTRODUCTION}

Highly efficient technological systems used in global forestry have been a standard since the beginning of the 1990s. In Scandinavia, over $90 \%$ of the total timber volume is harvested in this way (Nordfjeld et al. 2010). In countries with forest management similar to that in Poland, such as Germany or the Czech Republic, the share of harvesters in overall timber harvesting already amounts to over $40 \%$. In Poland, approx. 35\% of merchantable timber is currently being harvested in this way (Moskalik et al. 2017), the number of harvesters has increased over tenfold since the 1990s and currently amounts to approx. 530 units (Mederski et al. 2016). The semi-automatic and the machine levels of technology, assuming the use of harvesters and forwarders, is used not only in single-storey and singlespecies lowland stands. Technical capabilities are such that adequate profitability of machine timber harvesting is also obtained under mountain conditions, in structurally diverse stands (including deciduous ones) and in post-disaster stands (Moskalik and Stampfer 2003; Mederski 2006, 2013; Frutig et al. 2007; Dvořak 2011; Szewczyk 2011b; Fulvio et al. 2012; Yoshioka et al. 2012). The high economic effectiveness of such technological systems is associated with their high efficiency (Moskalik 2004; Spinelli et al. 2009; Szewczyk and Kulak 2013).

Even in highly developed countries, such as Germany, Italy or Austria, machine-level technologies are complementary to classical manual-machine systems (Sowa et al. 2007; Sauter and Siemens 2008; Savelli et al. 2010; Stankić et al. 2012; Proto et al. 2013). Tree felling and bucking are done with the use of chainsaws, while timber extraction is performed by farm or specialist tractors (Gil 2007; Findeisen et al. 2008; Szewczyk 2010; Magagnotti and Spinelli 2011). Inconveniences of using such solutions have been noticed for years, for example, non-ecological cable skidding from the stand or the non-ergonomic worksite of the chainsaw operator. However, due to the often difficult working conditions, the common use of machines and the relatively low costs of their purchase, such solutions are often implemented.

In the foreseeable time span, therefore, the complementary model of timber harvesting and extraction will continue to operate in forest management. Apart from machine technologies, such a model assumes the application of technologies at the manual-machine level.

A key element of work efficiency analysis consists of determination of task performance time. In forestry, the construction of time standards is difficult due to high variability resulting both from the personality features of employees and from many factors that influence task performance. There are numerous studies that document the influence of environmental factors on the time-consumption of production processes observed in operating areas (Więsik and Nurek 2002; Moskalik 2004; Więsik et al. 2005; Szewczyk 2011 b; Visser and Spinelli 2012; Jourgholami et al. 2013; Tsioras et al. 2013). However, there are few studies devoted to the share of non-production times (complementary work times) and factors that influence them (Morat et al. 1998; Nurek 2007). Their importance in the overall economic calculation is evident in the machine exploitation efficiency achieved by harvesters, which is lower by up to several hundred percent as compared to operational efficiency (Więsik et al. 2005; Jabłoński 2006).

Precise determination of the share of complementary work times in a work shift is very labour-intensive and requires time measurement by the working day picture method or the snapshot observation method (Szewczyk 2014a, b, 2017; Pszenny et al. 2019). Less frequent analyses based on surveys yield good results but require specific sociological research tools (Szewczyk et al. 2015; Kamiński and Wajda 2015; Kamiński et al. 2016; 2018). For this reason, the total share of productive work time PW in a work shift is estimated roughly, equally for all timber harvesting conditions. The remaining time in a shift is complementary work time CW, which includes: supportive work time SW, non-work time NT, travel time TR. In such proceedings, it is assumed that the structure of time of entire work shifts is very stable and does not depend on the influence of work environment factors, which seems to be a simplification.

The aim of this study was to determine the influence of work environment factors on the share of complementary work times in a work shift in the case of the manual-machine and the machine level technologies. It was assumed that the work environment factors affecting the share of complementary work times in the work shift for technologies at the manual-machine and the 
machine level are the features of timber being bucked as well as selected parameters of stands, their structure and level of accessibility.

\section{Material AND MEthods}

The research was carried out in the southern part of Poland, in the Regional Directorate of State Forests in Wrocław, in all 33 forest districts which belong there. That area, with the size of over 550 thousand ha, is very diverse geographically. Mountains constitute its largest part; while in the north and north-east, there are uplands and lowlands. Large diversity is also characteristic of environmental factors associated with forest management. Forest districts with a network of roads with a high density index offer favourable conditions for forest machines. Better terrain accessibility reduces the distance between operating areas. This translates into a smaller share of activities in the field of machine transport time and into breaks in a work shift. The analysed variable was presented as an indicator of the ratio of forest road length to the forest area of a forest district. Extreme values of road network density in the investigated forest districts reach values from $0.52 \mathrm{~km} / 100$ ha in the Henryków Forest District to $6.05 \mathrm{~km} / 100$ ha in the Swidnica Forest District. The age structure of stands is shaped by biotic, abiotic and historical factors, for example, forest districts affected by natural disasters often have an increased share of even-aged stands. Cultivation treatments carried out in the stands of the $2^{\text {nd }}$ age class show higher time consumption as compared to the stands of older age classes. The time consumption of timber harvesting and extraction, including the share of complementary work times, decreases with stand age. The share of forest stands in the $2^{\text {nd }}$ age class reaches extreme values in the Świętoszów Forest District: $29.63 \%$ and the Świdnica Forest District: $9.52 \%$. The Forest Site Type as a sum of natural environment elements defines work environment factors in forestry. Work carried out among low vegetation of the forest floor, in uniform pine stands formed on permeable soils (e.g., dry coniferous forest or fresh coniferous forest), requires less time spent on removing obstacles, getting to know the operating area and so on. Reduced visibility or locally high soil irrigation may result in greater frequency of technological breaks related to the perfor- mance of unproductive work activities, such as searching for previously selected trees, extracting a disabled machine and so on. This feature was presented as the area percentage of mountain and upland site types (potentially less favourable for harvesting work) in relation to the total area of forest stands in a forest district. The dominant share of upland and mountain forest site types occurs in the following forest districts: Jugów, Bystrzyca Kłodzka, Szklarska Poręba, Lądek Zdrój, Zdroje and Świeradów Zdrój: 100\%. Few forest districts function in forest complexes that are compact in terms of area. The number of complexes and the forestage of a district determine the necessity of frequent, unproductive movement of machines to operating areas that are far from one another. Stands smaller than 100 ha were not included in the model construction due to the fact that their area usually amounts to several hectares and the use of machine timber harvesting in such stands is unprofitable. The degree of forest dispersion, measured by the number of forest complexes with an area of over $100 \mathrm{ha}$, varies in the investigated forest districts between 2 in the Ruszów and Świętoszów Forest Districts, and 32 in the Lwówek Śląski Forest District.

Field and laboratory research carried out in the years 2016-2020 was performed in two ways:

- Within the entire Directorate, surveys were performed concerning analyses of the working day structure in the timber harvesting and extraction technology at the manual-machine, the machine and the semi-automatic levels.

- For each forest district, analyses were performed concerning environmental factors potentially relevant to the share of complementary work times in a work shift.

The questionnaire was designed in such a way as to enable conducting research on work time in timber harvesting and extraction with the use of technologies and machines suitable for all levels of technology. The survey made it possible to collect information on the duration of activities disregarded for various reasons in the performance of the classical working day picture. The survey examined the respondents' professional experience gained as a result of multiple repetition of work. This revealed a broad picture covering the entire professional experience of a given worker. In this way, to some extent, the study area did not require the collection of an extensive database. 
WORK TIME STRUCTURE

FINAL CHART TO BE FILLED IN - - -

FILL IN THIS CHART WITH YOUR FIRST TRIAL CALCULATIONS. WHEN YOU MAKE SURE THEY ARE CORRECT, COPY THEM TO THE FINAL CHART.

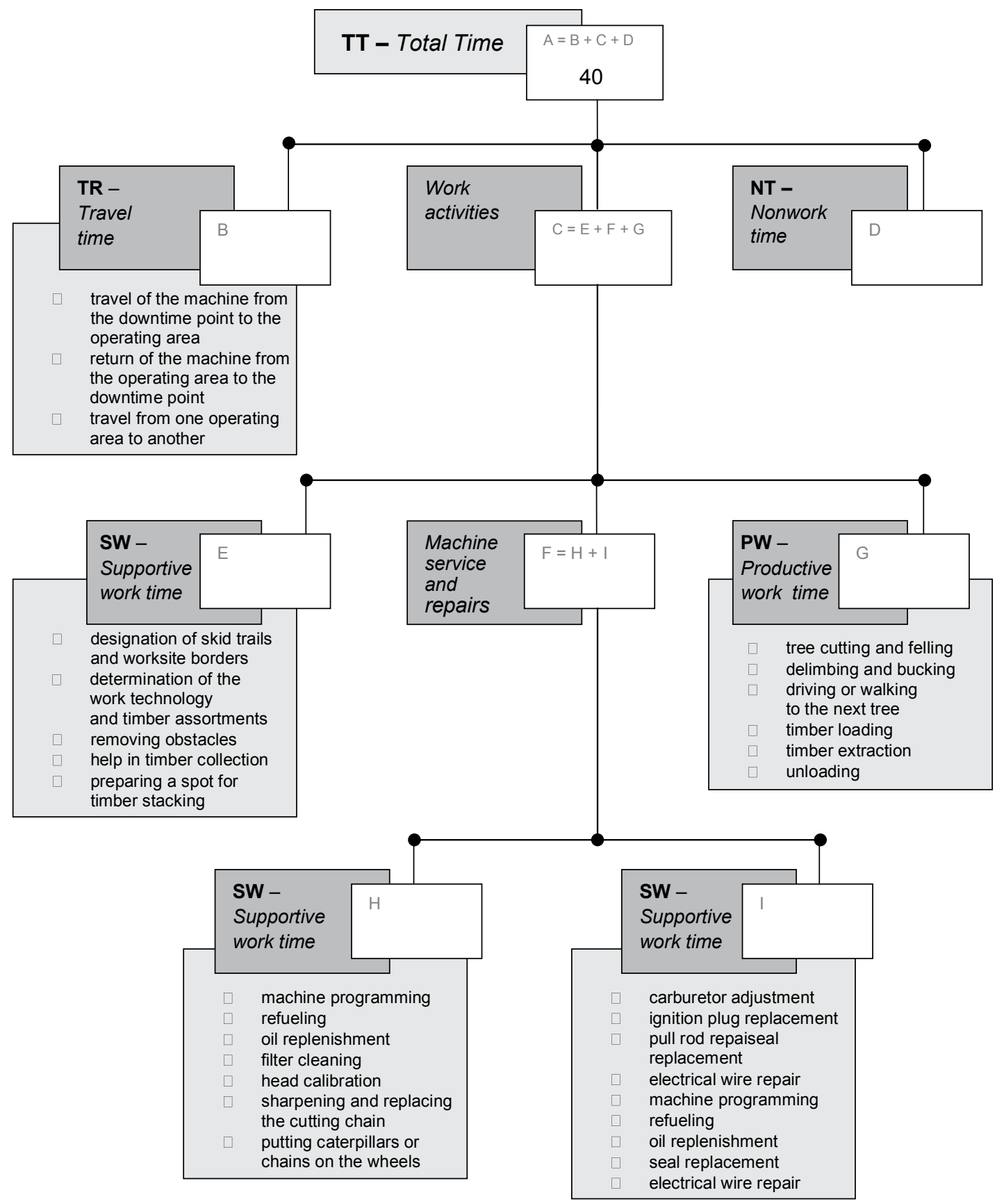

Figure 1. The survey designed to specify the working day structure of chainsaw operators and machine operators (IUFRO 1995) 
The survey was conducted among operators of chainsaws and various other machines. The survey ensured anonymity and voluntary participation. In order to protect the confidentiality of the collected data, the respondents received a questionnaire together with an empty envelope. In accordance with the instructions included in the survey, the questionnaire was returned in a sealed envelope. The questionnaire was based on the IUFRO standards regarding forest work study nomenclature (Björheden 1991; Szewczyk 2014 b; Szewczyk et al. 2014) in the form of a measurement diagram, which registered activities within four categories of work time (Fig. 1). It was assumed that the estimates of the working day structure performed with the use of surveys are more objective in a situation when the respondents define the share of individual time categories not in a single day but as a summary of the working week, where the total working time nominally amounts to 40 hours.

The survey contained a headline with information on its purpose, the institution conducting the research and the instruction how to fill it in. The questionnaire included the trial as well as the final sheet with a measurement chart, and another sheet with questions concerning a respondent's particulars. Respondents distributed 40 working hours (a working week) between sets and subsets of activities corresponding to the full work shift structure. The number of 40 hours enabled examination of the work shift structure on the scale of a cyclical work fragment that was the largest and at the same time easiest to reconstruct from memory by the respondent.

Among environmental factors potentially affecting the share of complementary work times, the impact of microfactors (local factors occurring in and around the operating area, limited only to the immediate vicinity of a division) was distinguished in contrast to macrofactors, affecting a much larger area (occurring within forest districts). Analysed was the spatial structure of stands, road infrastructure, inventory features of stands and management solutions adopted in the Forest Management Plan: the share of upland and mountain sites [\%], the share of coniferous forest sites [\%], the share of timber assortments with the length of over $2.5 \mathrm{~m}$ [\%], the number of forest complexes with the area of over 100 ha [each], road network density $[\mathrm{km} / 100 \mathrm{ha}]$. The empirical data to construct the model were obtained from Forest Management Plans in forest districts as well as the State Forests Information System (SILP).

The parameter applied in further analyses was the share of complementary work times CW (Tab. 1). Testing the conformity of the distribution of this feature with the normal distribution for harvesters, forwarders and the manual-machine level technologies was performed using the Shapiro-Wilk test at a significance level of 0.05 . The significance of differences in the share of $\mathrm{CW}$ times between the above groups was tested using the Student's t test.

Table 1. Time classification in a work shift (IUFRO 1995)

\begin{tabular}{|c|c|c|c|c|c|c|}
\hline \multicolumn{7}{|c|}{ TT - total time } \\
\hline \multirow{3}{*}{$\begin{array}{c}\mathbf{U N} \\
- \text { unu- } \\
\text { tilized } \\
\text { time }\end{array}$} & \multicolumn{5}{|c|}{$\mathbf{C W}$ - complementary work times } & \\
\hline & $\begin{array}{c}\text { NW } \\
\text { - non- } \\
\text {-work- } \\
\text { place } \\
\text { time }\end{array}$ & $\begin{array}{c}\mathbf{N T}- \\
\text { non-work } \\
\text { time }\end{array}$ & \multicolumn{3}{|c|}{$\begin{array}{c}\text { SW - supportive work } \\
\text { time }\end{array}$} & \multirow{2}{*}{$\begin{array}{c}\text { PW } \\
\text { - pro- } \\
\text { ductive } \\
\text { work } \\
\text { time }\end{array}$} \\
\hline & $\begin{array}{l}\mathbf{T R}- \\
\text { travel } \\
\text { time }\end{array}$ & $\begin{array}{l}\mathbf{R P}- \\
\text { rest and } \\
\text { personal } \\
\text { time }\end{array}$ & $\begin{array}{c}\mathbf{R F}- \\
\text { refuel } \\
\text { time }\end{array}$ & $\begin{array}{c}\text { MT } \\
\text { - main- } \\
\text { tenance } \\
\text { time }\end{array}$ & $\begin{array}{l}\text { RT - } \\
\text { repair } \\
\text { time }\end{array}$ & \\
\hline
\end{tabular}

The relationship between the share of $\mathrm{CW}$ times in the machine level technologies and the work environment features was determined by applying the nonlinear regression (formula 1).

$$
\begin{gathered}
Y_{1}=\left(a+b \times x_{1}\right)+\left(c \times \log 10\left(x_{2}\right)\right)+ \\
+\left(d \times \exp \left(e \times x_{3}\right)\right)
\end{gathered}
$$

where:

$Y_{1}$ - share of CW complementary work times in the machine timber harvesting model [\%],

$x_{1}$ - share of coniferous sites [\%],

$x_{2}$ - number of forest complexes of over 100 ha [each],

$x_{3}-$ road length $[\mathrm{km} / 100 \mathrm{ha}]$.

The relationship between the share of $\mathrm{CW}$ times in technologies at the manual-machine level and the work environment features was determined by applying the multiple regression (formula 2).

$$
Y_{2}=\left(g+h \times x_{4}\right)+\left(j+k \times x_{5}\right)
$$


where:

$Y_{2}$ - share of CW complementary work times in the manual-machine timber harvesting model [\%],

$x_{4}$ - share of upland and mountain sites [\%],

$x_{5}$ - share of timber assortments with the length of over $2.5 \mathrm{~m}[\%]$.

Statistical calculations were performed using the Statistica 12 package.

\section{Results}

Each forest enterprise under analysis operated in several forest districts. The survey included men aged 25-40 years with several years of work experience. The respondents had secondary and higher education. Work in a given job was the respondents' main task; they did not perform any other jobs.

The database consisted of 87 surveys (measurement of 522 activities) concerning timber harvesting at the manual-machine level of technology and 21 surveys concerning the machine level of technology (126 activities).

The working day structure in the analysed technologies is presented in Figure 2. The total share of

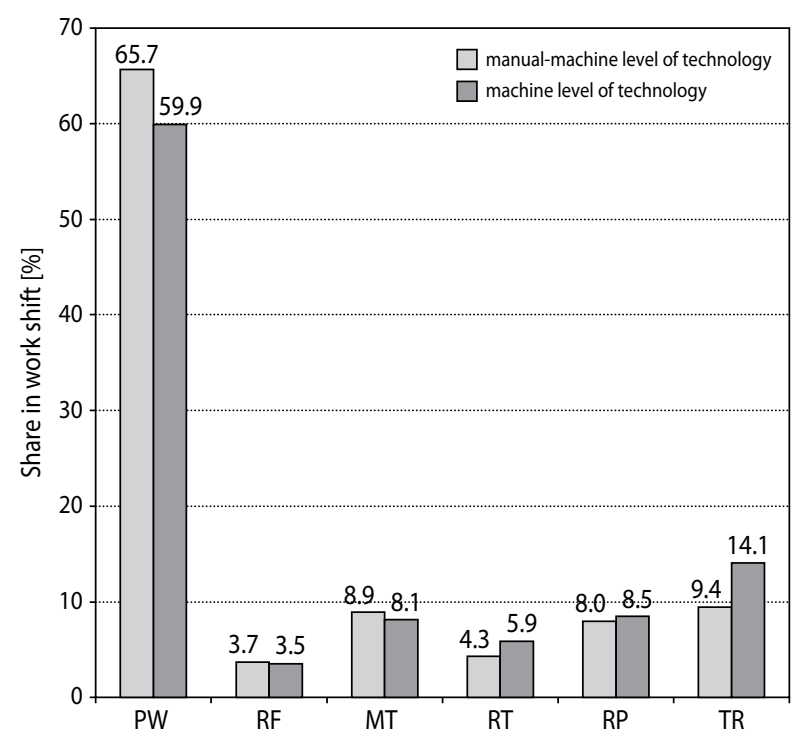

Figure 2. Share of the category of complementary work times in the manual-machine and the machine model of timber harvesting productive work time reached around $60 \%$ for machine technologies and around $65 \%$ for manual-machine technologies. Travel time had the largest share in the complementary work times group: around $9 \%$ in manual-machine technologies and around $14 \%$ in machine technologies. The share of break times amounted to approx. $8 \%$. The percentage of repair time, proving the reliability of machines and devices used, was relatively low (about 5\%) for the analysed variants.

The distribution of CW time share values for all of the analysed variables: harvesters, forwarders and technologies at the manual-machine level was consistent with the normal distribution (Tab. 2).

Table 2. Analysis of the normality of CW time distribution in the analysed technologies

\begin{tabular}{|l|l|c|c|}
\hline Technology level & \multicolumn{1}{|c|}{ Machine } & $\begin{array}{c}\text { Shapiro-Wilk } \\
\text { test }\end{array}$ & $\mathrm{p}$ \\
\hline \multirow{2}{*}{ Machine } & harvester & 0.88 & 0.06 \\
\cline { 2 - 4 } & forwarder & 0.86 & 0.15 \\
\hline Manual-machine & $\begin{array}{l}\text { chainsaw, farm } \\
\text { tractor, skidder... }\end{array}$ & 0.99 & 0.63 \\
\hline
\end{tabular}

The share of CW times was found to be by approx. $10 \%$ higher in a work shift with forwarders as compared to harvesters, but these differences were not statistically significant (Fig. 3). There were, however, documented differences between the share of analysed work time categories in the machine-level technologies and the manual-machine technologies (Fig. 4).

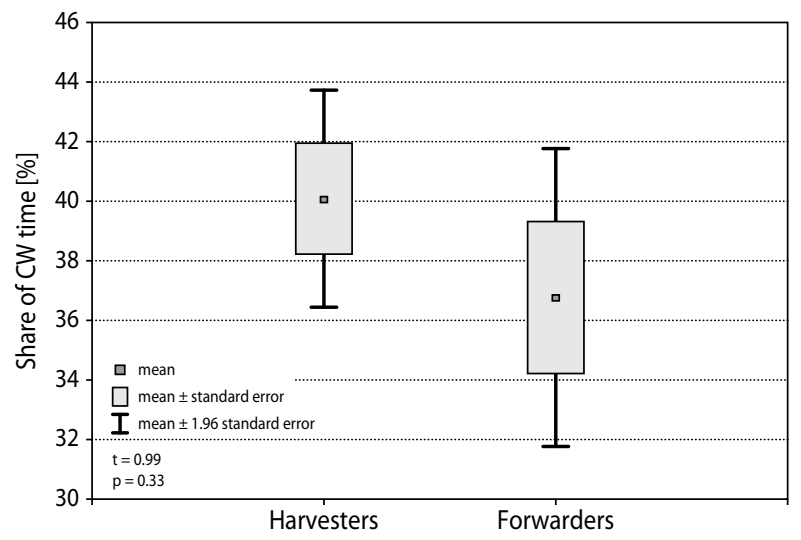

Figure 3. Share of complementary work times in a work shift with harvesters and forwarders 


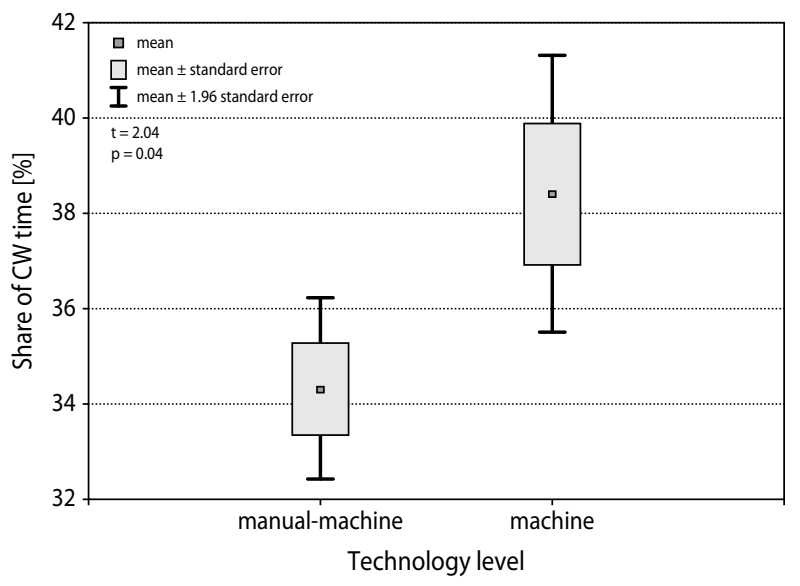

Figure 4. Share of complementary work times in a work shift in technologies at the manual-machine level and the machine level

The influence of the analysed work environment features on the share of $\mathrm{CW}$ times was presented using models of dependence of the analysed work time categories on the frequency of a given work environment feature (Tab. 3). Among the examined features of the work environment, the largest influence on the share of $\mathrm{CW}$ times in timber harvesting technologies at the machine level was exerted by the share of coniferous sites characteristic of lowland areas with favourable orography, the length of roads in kilometres per 100 ha and the number of forest complexes with an area of over 100 ha each, which testified to the dispersion of stands. In the case of timber harvesting in technologies at the manual-machine level, the share of $\mathrm{CW}$ times depended on the share of timber assortments with the length of over $2.5 \mathrm{~m}$, and on the share of upland and mountain sites.
The total influence of the selected factors of the work environment on the share of $\mathrm{CW}$ time in the machine model of timber harvesting was determined with the use of the following equation (formula 8).

$$
\begin{gathered}
Y_{3}=\left(708.503-0.145 \times x_{1}\right)+(-640.531+ \\
\left.-21 \times \log 10\left(x_{2}\right)\right)+\left(-0.012 \times \exp \left(x_{3}\right)\right) \\
\mathrm{R}=0.67 ; \mathrm{p}<0.00
\end{gathered}
$$

where:

$Y_{3}$ - share of CW complementary work times in the ma-

chine model of timber harvesting [\%],

other symbols as given in Table 3 .

The total influence of selected work environment factors on the share of $\mathrm{CW}$ time was determined using the following equation (formula 9).

$$
\begin{gathered}
Y_{4}=41.2416+0.0552 \times x_{4}-0.1664 \times x_{5} \\
\mathrm{R}=0.57 ; \mathrm{p}<0.00
\end{gathered}
$$

where:

$Y_{4}$ - share of $\mathrm{CW}$ complementary work times in the manual-machine model of timber harvesting [\%], other symbols as given in Table 3 .

For highly variable conditions of timber harvesting, the models presented explain complementary work time variability quite well ( $45 \%$ and $33 \%$ ), as indicated by the values of the coefficient of determination $\mathrm{R}^{2}$. The obtained values of coefficients of determination in equation 9 indicate that the share of complementary work times in manual-machine level technologies was influenced more by the share of upland and mountain sites $(\beta=0.35)$ than by the share of timber assortments with the length of over $2.5 \mathrm{~m}(\beta=-0.29)$.

Table 3. Parameters of regression equations for $\mathrm{CW}$ time dependence on selected features of the working environment

\begin{tabular}{|l|ll|c|c|}
\hline \multicolumn{1}{|c|}{ Technology level } & \multicolumn{1}{|c|}{ Model [\%] } & Correlation coefficient $\mathrm{R}$ & Significance level $\mathrm{p}$ \\
\hline \multirow{3}{*}{ Machine } & $Y_{11}=41.0804+-0.1598 \times x_{1}$ & $(3)$ & 0.93 & 0 \\
\cline { 2 - 5 } & $Y_{12}=32.9369 \times \log 10\left(x_{2}\right)$ & $(4)$ & 0.67 & 0 \\
\cline { 2 - 5 } & $Y_{13}=76.9390 \times \exp \left(-0.2411 \times x_{3}\right)$ & $(5)$ & 0.86 & 0 \\
\hline \multirow{2}{*}{ Manual-machine } & $Y_{21}=51.8577+-0.2788 \times x_{4}$ & $(6)$ & -0.48 & 0 \\
\cline { 2 - 5 } & $Y_{22}=29.646+-0.066 \times x_{5}$ & $(7)$ & 0.37 & 0 \\
\hline
\end{tabular}

* Dependent variable used: $Y_{11}-Y_{13} ; Y_{21}-Y_{22}$ - share of complementary work time in machine level technologies.

Independent variables used: $x_{1}$ - share of coniferous sites [\%]; $x_{2}-$ number of forest complexes with an area of over 100 ha [each]; $x_{3}-$ road length [km/100 ha]; $x_{4}$ - share of timber assortments with the length of over $2.5 \mathrm{~m}[\%] ; x_{5}-$ share of upland and mountain sites [\%]. 


\section{Discussion}

Technical and technological optimization of worksites must include the aspect of working time standardization. The basic purpose of standardization is to determine the real level of time consumption under given conditions. Work time standardization at worksites is usually carried out on two levels: of measurement and estimation. What is measured is the productive work time. This time characterizes the variability of terrain conditions in the best way. Complementary work times are connected with the execution of steps that enable the performance of the main work. Their share in a work shift is estimated based on the measured productive work time. The estimation error included in such a performance model has so far been undefined. It is assumed that the efficiency of the timber harvesting process, as a resultant of numerous variables that stem from stand characteristics, terrain conditions, techniques and technologies applied as well as the psychomotor characteristics of the human being, has a number of interrelations that can be presented in the form of mathematical models. However, this also applies to the wide spectrum of non-production activities, including complementary work times. Such an approach has not been applied so far.

In the present research, the share of productive work time amounted to approx. $60 \%$ in the machine and semiautomatic technological systems, while in the manualmachine technologies, it reached $65 \%$. What was characteristic was its large variability, also described earlier by other authors (Zečić et al. 2005). According to Nurek (2007) and Brzózka (2014), its share can reach up to $50 \%$. In technologies at the manual-machine level, the share of productive work time was slightly lower and amounted to around $30 \%$ up to approx. $90 \%$. This clearly shows the beneficial effect of mechanization of tasks, which are characterized by a lower level of energy expenditure and thus less frequent rest breaks for workers (Axelsson and Pontén 1990; Ager 2014). This phenomenon is particularly visible in operations characterized by high work intensity, which in the discussed technologies occurs especially during timber manipulation (Szewczyk 2011a; Szewczyk and Stańczykiewicz 2012; Sowa and Szewczyk 2013; Kulak et al. 2019).

The results obtained in the course of the present research are consistent with the results obtained by other researchers. According to Nurek (2007), Nurminen et al.
(2006) and Picchio et al. (2012), the share of ancillary work times in the work shift of multi-operational machines ranges from 40 to $60 \%$. The low work flexibility (sensitivity to factors of the work environment in terms of complementary work times and preparation-completion times) of high-performance multi-operational machines was demonstrated during the analyses of work in postdisaster stands. Stempski (2012) noted that the share of effective activities decreased to $50 \%$ of the work shift time as a result of applying a work technology different from the standard one, consisting of the concentration of harvesting residue in regular stacks next to mediumsized timber packets. Brzózko (2009) showed a reduction in the efficiency of machine operation by 40 to $60 \%$ in stands damaged by wind. Sadowski et al. (2014) and Nurminen et al. (2006), who examined the effectiveness of machine timber harvesting, noted the decreasing work flexibility in stands of younger age classes. In mature stands, it amounted to $144 \mathrm{~m}^{3} / \mathrm{day}$, while in thinning stands, it was at the level of $68-90 \mathrm{~m}^{3} /$ day. The difference in efficiency was caused, among other factors, by the sometimes longer vehicle maintenance travel times and travel between worksites.

The model proposed by Nurek (2007) to assess the efficiency of machine timber harvesting, comprehensive, and taking into account non-work times, was constructed on the basis of four groups of factors: 1) the area in which the activities are carried out, 2) the size of tasks, 3) timber recipients, 4) machines used. In our study, these factors were supplemented with variables associated with the type of forest site, the harvested timber as well as the dispersion of tasks and their number in the context of the timber harvesting size. Moreover, Nurek's model did not take into account the spatial distribution of the studied features and did not use field measurements to verify the model.

In the State Forests, there are solutions similar to those presented in this study, but they do not take into consideration the structure of the work time of forest contractors. The method developed by the Forest Research Institute to determine the degree of forest management difficulty in forest districts presents a method of ranking those work environment factors that affect task performance by field employees of the Forest Service. Comprehensive studies have shown the complex nature of the impact of work environment factors on the duration of tasks. Ranking the impact of field fea- 
tures was used to determine a synthetic indicator of management difficulty of forest districts (Kwiecien and Kocel 2006) and forest ranges (Kocel and Kwiecień 2004, 2012; Kocel et al. 2012). Similar to the present research, studies by Kocel and Kwiecień pointed to, among others, spatial elements of forests in a forest district/forest range (forest district area), the management solutions applied (timber harvesting size), demographic factors (population density and forest district area) as well as stand classification (appraisal) features (area of: age classes, forest site types, stands with the main forest-forming species) as factors affecting the degree of difficulty in the work of employees of forest districts and ranges. The ranking of impact of environmental features present in the above-mentioned studies, and to some extent discretionary, was in our analyses confronted with more objective surveys of the working day structure of chainsaw and machine operators.

The above considerations confirm the assumption adopted in our study, according to which the work environment factors that affect the share of complementary work times $\mathrm{CW}$ in a work shift include: terrain, stand structure, the type of timber assortments obtained and road network density.

\section{Conclusions}

The total share of complementary work times reached approx. $40 \%$ for technologies at the machine level and approx. $35 \%$ for technologies at the manual-machine level.

The dominant impact on the share of complementary work times in the case of timber harvesting in manual-machine technologies was exerted by the share of timber assortments with the length of over $2.5 \mathrm{~m}$ and the share of upland and mountain sites. On the other hand, in the case of timber harvesting at the machine level technology, it was the share of coniferous forest sites, the number of forest complexes with an area of over 100 ha and the total length of roads that had a significant impact on the share of complementary work times.

The environment factors distinguished in the course of the present research have a varied influence on the work process. Therefore, in order to indicate homogeneous areas in terms of the share of complementary work times, the influence of these factors should be ranked.

\section{ReferenCes}

Ager, B. 2014. Forestry labors' humanization and rationalization from 1900 onwards (in Swedish with English summary). Ph.D. thesis. Luleå University of Technology.

Axelsson, S.-Å., Pontén, B. 1990. New ergonomic problems in mechanized logging operations. International Journal of Industrial Ergonomics, 5, 267-273.

Björheden, R. 1991. Basic time concepts for international comparison of time study reports. Journal of Forest Engineering, 2, 33-39.

Brzózko, J. 2009. Wood harvesting from calamity areas risk factors and methods of work safety increasing (in Polish with English summary). Technika Rolnicza Ogrodnicza Leśna, 1, 10-12.

Brzózko, J. 2014. The method of forecasting of windthrown wood machine harvesting performance based on the characteristics of the damaged forest area (in Polish with English summary). Scientific Dissertations and Monographs, 449. Wydawnictwo SGGW, Warszawa.

Dvořak, J. 2011. Small forwarders performance standards. Monography: Technology and ergonomics in the service of modern forestry. University of Agriculture in Krakow, 487-494.

Findeisen, E., Markoff, I., Gluschkov, S. 2008. Fully mechanized logging in Bulgaria - first steps and prospects. In: Formec 08, 41 International Symposium in Schmallenberg, Germany.

Frutig, F., Fahrni, F., Stettler, A., Egger, A. 2007. Mechanisierte Holzernte in Hanglagen. Wald und Holz, 4, 47-52.

Fulvio Di, F., Bergström, D., Kons, K., Nordfjell, T. 2012. Productivity and profitability of forest machines in the harvesting of normal and overgrown willow plantations. Croatian Journal of Forest Engineering, 1, 25-37.

Gil, W. 2007. Comparative studies of agricultural tractors as wood extraction means in selected forest service companies (in Polish with English summary). Zeszyty Naukowe Akademii Rolniczej w Krakowie, 435 (316), 1-128

Grzywiński, W. 2007. Ergonomics and labor protection in forestry (in Polish with English summary). University Publisher, Poznan University of Life Science. 
IUFRO. 1995. WP 3.04.02. Forest work study nomenclature. Test editio valid 1995-2000. Department of Operational Efficiency, Swedish University of Agriculture Science, Garpenberg.

Jabłoński, K. 2006. Optimization models for the technological process of wood harvesting and extraction in a given forest area (in Polish with English summary). University Publisher, Poznan University of Life Science.

Jourgholami, M., Majnounian, B., Zargham, N. 2013. Performance, capability and costs motor-manual tree felling in Hyrcanian hardwood forest. Croatian Journal of Forest Engineering, 34 (2), 283-293.

Kamiński, K., Szewczyk, G., Sowa, J. 2016. Application possibilities of surveys in the analysis of time-consuming processes of logging (in Polish with English summary). Conference of the Homonymous Forests Departments 'The importance of forest use in 21st century forest management'.

Kamiński, K., Szewczyk, G., Sowa, J., Czarnik, S. 2018. Surveys in the measurement of the structure of the work shift at harvesting and skidding. In: Interdisciplinarity of Forest Use. Forest Departments Homonymous Conference, Krynica Zdrój.

Kamiński, K., Wajda, M. 2015. The Exactitude of Evaluating Non-operational Work Time in Mechanised Technologies of Timber Harvesting. In: IV International Conference of PhD Students. Multidirectional Research in Agriculture and Forestry, Krakow.

Kocel, J., Kwiecień, R. 2004. Degree update of indicators of difficulty management in State Forests (in Polish with English summary). Forest Research Institute, Warsaw.

Kocel, J., Kwiecień, R. 2012. Methodological foundations of determining the indicator of the degree of management difficulty in the State Forests forest ranges (in Polish with English summary). Sylwan, 156 (2), 118-127.

Kocel, J., Kwiecień, R., Młynarski, W., Mionskowski, M. 2012. Management Difficulty Index in the forest ranges of the State Forests (in Polish with English summary). Sylwan, 156 (6), 403-413.

Kulak, D., Stańczykiewicz, A., Szewczyk, G., Wala, Ł. 2019. Efficiency of timber skidding on the slopes (in Polish with English summary). Sylwan, 163 (7), 601-609. DOI: https://doi.org/10.26202/sylwan. 2019003
Kwiecień, R., Kocel, J. 2006. The method of determining the management difficulty degree for forest district administration (in Polish with English summary). Leśne Prace Badawcze, 2, 51-71.

Magagnotti, N., Spinelli, R. 2011. Integrating animal and mechanical operation in protected areas. Croatian Journal of Forest Engineering, 32 (2), 489-499.

Mederski, P.S., Karaszewski, Z., Rosińska, M., Bembenek, M. 2016. Dynamics of harvester fleet change in Poland and factors determining machine occurrence (in Polish with English summary). Sylwan, 160 (10), 795-804.

Mederski, P.S. 2006. A comparison of harvesting productivity and costs in thinning operations with and without midfield. Forest Ecology and Management, 224, 286-296.

Mederski, P.S. 2013. The potential of harvester use for thinning operations in mixed birch-pine stands (in Polish with English summary). University Publisher, Poznan University of Life Science, Poznan.

Morat, J., Forbrig, A., Graupner, J. 1998. Holzernteverfahren - Vergleichene Erhebung und Beurteilung der Beurteilung der Holzernteverfahren in der Bundesrepublik Deutschland. KWF Bericht, 25.

Moskalik, T. 2004. Model of fully mechanized timber harvesting in sustainable Polish forestry (in Polish with English summary). Dissertations and Monographs. Warsaw University of Life Science, 276.

Moskalik, T. et. al. 2017. Timber Harvesting Methods in Eastern European Countries: a Review. Croatian Journal of Forest Engineering, 38 (2), 231-241.

Moskalik, T., Stampfer, K. 2003. Productivity of the harvester Valmet 911 Snake under the mountain conditions (in Polish with English summary). Sylwan, 4, 91-98.

Natov, P., Dvoŕak, J. 2018. Doporučená pravidla pro elektronický př́ijem dřiví harvestory v ČR 2018. Czech University of Life Sciences, Prague.

Nordfjeld, T., Bjorheden, R., Thor, M., Wästerlund, I. 2010. Changes in technical performance, mechanical availability and prices of machines used in forest operations in Sweden from 1985 to 2010. Scandinavian Journal of Forest Research, 25 (4), 382-389.

Nurek, T. 2007. Method of estimation of efficiency of machine wood harvesting in conditions of Polish forests (in Polish with English summary). Disserta- 
tions and Monographs. Warsaw University of Life Science.

Nurminen, T., Korpunen, H., Uusitalo, J. 2006. Time consumption analysis of the mechanized cutto-length harvesting system. Silva Fennica, 2, 335-363.

Picchio, R., Sirna, A., Sperandio, G., Spina, R., Verani, S. 2012. Mechanized harvesting of eucalypt coppice for biomass production using high mechanization level. Croatian Journal of Forest Engineering, 1, 15-24.

Proto, A.R., Bernardi, B., Zimbalatti, G. 2013. Productivity and cost analysis of a John Deere skidder in South Italy. In: Fortechenvi. Mendel University in Brno.

Pszenny, D., Giedrowicz, A., Staniszewski, P., Moskalik, T. 2019. Accurancy of working day structure determining of the timber skiddingby snapshot observations. Sylwan, 163 (4), 292-299.

Sadowski, J., Moskalik, T., Zastocki, D. 2014. The effectiveness of the timber harvesting by PONSSE Ergo harvester in selected forest stand (in Polish with English summary). Studia i Materiaty Centrum Edukacji Przyrodniczo-Leśnej, 16, 2B (39), 126-132.

Sauter, U.H., Siemens, P. 2008. Harvesting and processing systems for large dimensioned timber (LTD) as short logs. In: Formec '08, 166-172.

Savelli, S., Cavalli, R., Baldini, S., Picchio, R. 2010. Small scale mechanization of thinning in artificial coniferous plantation. Croatian Journal of Forest Engineering, 31 (1), 11-21.

Sowa, J.M., Kulak, D., Szewczyk, G. 2007. Costs and efficiency of timber harvesting by NIAB 5-15 processor mounted on a farm tractor. Croatian Journal of Forest Engineering, 28 (2), 177-184

Sowa, J.M., Leszczyński, K. 2000. Changes in the level of threats of machine operators during wood harvesting (in Polish with English summary). In: Proceedings of 3rd Forest Conference: The state and perspectives of research on forest use (eds.: M. Suwała, S. Rzadkowski), Sękocin Las, 30-31 March 2000, IBL, Warsaw, 412-424.

Sowa, J.M., Szewczyk, G. 2013. Time consumption of skidding in mature stands performed by winches powered by farm traktor. Croatian Journal of Forest Engineering, 34 (2), 255-265.
Spinelli, R., Ward, S.M., Owende, P.M. 2009. A harvest and transport cost model for eucalyptus spp. fastgrowing short rotation plantations. Biomass and Bioenergy, 33, 1265-1270.

Stankić, I., Poršinsky, T., Tomašić, Ž., Tonković, I., Frntić, M. 2012. Productivity models for operational planning of timber forwarding in Croatia. Croatian Journal of Forest Engineering, 33 (1), 61-78.

Stempski, W. 2012. Efects of wood layout on the forming time with a Forwarder (in Polish with English summary). Science Nature Technologies, 6, 4.

Szewczyk, G. 2010. Time consumption of horse skidding operations in thinned stands (in Polish with English summary). Sylwan, 154 (1), 52-63.

Szewczyk, G. 2011 a. Time consumption of skidding operations using winches aggregated with chainsaws in thinned stands (in Polish with English summary). Sylwan, 155 (6), 401-412.

Szewczyk, G. 2011 b. Variability of the harvester operation time in thinning and windblow areas. Technology and ergonomics in the service of modern forestry. Monography. Publishing House of the University of Agriculture in Krakow.

Szewczyk, G. 2014 a. Snapshot observations in work measurement during timber harvesting and skidding (in Polish with English summary). Sylwan, 158 (11), 803-810.

Szewczyk, G. 2014 b. Structural models of work variability dynamics at selected worksites in timber harvesting and skidding (in Polish with English summary). Scientific Papers of the Agricultural University in Krakow, 522. Dissertation 399, 174.

Szewczyk, G. et al. 2014. Sequencing of harvester work during standard cuttings and in areas with windbreaks. Silva Fennica, 48 (4), 1-16. DOI:10.14214/ sf.1159

Szewczyk, G., Kulak, D. 2013. Cost effectiveness of timber harvest with a harvester in the stands rebuilt under the shelterwood system (in Polish with English summary). Sylwan, 4, 243-252.

Szewczyk, G., Sowa, J., Jamrozik, M. 2015. Complementary and preparatory-completion times in harvesting and logging technologies at the manualmachine level of technology (in Polish with English summary). In: VII International Scientific Conference: Use of agricultural and forestry machinery, scientific research and didactics. Zakopane. 
Szewczyk, G., Stańczykiewicz, A. 2012. A model for estimating labour requirements during timber harvesting in snowbreak stands (in Polish with English summary). Leśne Prace Badawcze, 73 (2), 167-173.

Szewczyk, G., Sowa, J.M. 2017. The accuracy of measurements in a time study of harvester operations. New Zealand Journal of Forestry Science, 47, 24.

Tsioras, P.A., Efthymiou, P.N., Liamas, D.K. 2013. Work efficiency of whole-steam and full-tree harvesting systems in steep terrain. Conference materials: FORTECHENVI. Brno.

Visser, R., Spinelli, R. 2012. Determining the shape of the productivity function for mechanized felling and felling-processing. Journal of Forest Research, 17, 397-402.

Więsik, J., Nurek, T. 2002. The perspectives of exploitation of wood harvesters in Poland (in Polish with
English summary). Zeszyty Problemowe Postępów Nauk Rolniczych, 486, 245-252.

Więsik, J., Nurek, T., Dybcio, M. 2005. Mathematical model of the harvester's work. (in Polish with English summary). Technika Rolnicza Ogrodnicza Leśna, 9-10, 45-48.

Yoshida, M. 2013. Availability of a low-investment mobile chip per for small-scale forestry. In: Fortechenvi. Mendel University in Brno, 22.

Yoshioka, T., Sugiura, K., Inoue, K. 2012. Application of a sugarcane harvester for harvesting of willow trees aimed at short rotation forestry: an experimental case study in Japan. Croatian Journal of Forest Engineering, 1, 5-14.

Zečić, Ž., Krpan, A.P.B., Vukušić, S. 2005. Productivity of $\mathrm{C}$ Holder $870 \mathrm{~F}$ tractor with double drum winch Igland 4002 in thinning beech stands. Croatian Journal of Forest Engineering, 26 (2), 49-56. 